\author{
Anna Agnieszka Musioł \\ Uniwersytet Śląski \\ (D) https://orcid.org/0000-0001-7325-4456
}

\title{
Wybrane aspekty filozofii w coachingu: refleksje nad wiedzą humanistyczną a coachingowa praktyka
}

\author{
Selected aspects of philosophy in coaching: \\ Reflexions on humanistic knowledge \\ and the practice of coaching
}

\begin{abstract}
In this paper I undertake anattemptindication of dependences binding philosophy with coaching. Round the coaching grew many myths. Thereby in the paper I refer coaching as the present form of helping professions with the second man (with the customer/ coachee); the profession whose method and the tool reach philosophical thought of different epochs, determining a permanent foundationunder the humanities. This foundation determines till now elaborate by thinkers the knowledge about the man, to his form and the place in the world. The reflection over philosophical aspects in coaching I begin from the description of chosen thoughts the ancient epoch in which the philosophy - accenting its own practical character - appears as art of living; across analysis of the meaning of Max Scheler and Nicolai Hartmann axiological ethics; finishing of the twentieth century eternal philosophy of dialogue.
\end{abstract}

Key words: ancient philosophy, philosophy of dialogue, ethics, axiology, art of living, coaching, Socrates, Hartmann, Buber, Tischner 


\section{Wstęp}

Coaching, zwłaszcza w Polsce, to względnie młoda, nie w pełni jeszcze ukształtowana dyscyplina pracy z drugim człowiekiem (klientem/coachee) $\mathrm{i}$ jego zasobami. $Z$ tego powodu coachingowe postępowanie należy do zjawisk rachitycznych ${ }^{1}$. Pomimo że coaching jako forma pracy z ludzkim potencjałem czerpie z nauk, zwłaszcza z psychologii i filozofii, to nie posiada on statusu dyscypliny naukowej. Wszelki trud obdarowania coachingu tym tytułem jest przesadą, a nierzadko nadużyciem. Coaching bowiem to zespół metod i narzędzi stosowanych w interaktywnym procesie dialogicznej współpracy dwóch lub więcej osób. Proces ten naznaczony jest dyrektywami podopiecznego (klienta/coachee) i tak rozumiany staje się, pokonywaną w określonym czasie, drogą ku wyznaczonemu celowi; innymi słowy jest to proces samodzielnego przecierania szlaku pokonywanego przez coachee w asyście coacha, w określonym czasie. Proces ten znaczony jest nieprzypadkowością, gdyż przebiega w sposób planowy, przemyślany, zamierzony i konsekwentny. Tę planowość oraz konsekwencję wyznaczają coachingowe struktury ${ }^{2}$.

W artykule podejmuję próbę ukazania coachingu jako procesu interpersonalnej współpracy; lub, pisząc metaforycznie, procesu kroczenia drogą wybrukowaną elementami wiedzy humanistycznej, której podmiotem właściwym jest człowiek jako jednostka. Specyfika podjętego problemu w pierwszej kolejności nakłada na mnie obowiązek przytoczenia definicji coachingu oraz wymusza podjęcie wysiłku opisania sposobów jego zastosowania w obszarach, w których coaching cieszy się dużym powodzeniem i skutecznością.

Otóż, jak pisze praktykująca facylitatorka, coach i trener Barbara Zych: „wczesny etap rozwoju coachingu w naturalny sposób wiąże go z dyscyplinami pokrewnymi, posiadającymi dłuższą historię zastosowań. Są to między innymi: zarządzanie, doradztwo zawodowe, szkolenia, a w przypadku

${ }^{1}$ Słowa „rachityczny” używam w celu określenia coachingu jako dziedziny stosunkowo młodej, niebędącej dyscypliną naukową, nieposiadającej stabilnego zaplecza naukowego, mającej charakter interdyscyplinarny a w Polsce niemającej jeszcze precyzyjnie dookreślonych przepisów regulujących. W tym miejscu warto jednak dodać, że na wniosek Izby Coachingu, decyzją Ministra Pracy i Polityki Społecznej, 1 lipca 2014 roku profesja coach została umieszczona w klasyfikacji zawodów i specjalności. Zob. URL: www.swiatcoachingu.pl/2011-09-27-04-13-15/definicja/440-zawod-coach-w-klasyfikacji-zawodow-ispecjalnosci [09.10.2020].

${ }_{2}^{2}$ Wśród coachingowych struktur wyróżnić można między innymi strukturę: GROW, STEPPPA, G-WAVE, STORM, GOLD, DROPS, STAGES i wiele innych. 
coachingu osobistego zwanego także coachingiem życiowym (personal coachingiem lub life coachingiem), to także różnego rodzaju szkoły psychoterapeutyczne czy inne źródła wiedzy psychologicznej”3.

Takiemu ujęciu coachingu sprzyja głęboko humanistyczny klimat umożliwiający autorefleksję, samopoznanie, zaznajomienie się coachee z własnymi możliwościami, które w sytuacji samodzielnej i przepracowanej w myślach odpowiedzi na kluczowe dla niego kwestie przyznoszą satysfakcję i radość z samodzielnego kroczenia do wyznaczonego miejsca lub celu. Oczywiście, to podopieczny coacha podpowiada tematykę procesu, jest również donatorem wszelkich wnoszonych $\mathrm{w}$ proces treści, a zarazem jest źródłem wiedzy, którą niejako wydobywa z siebie podczas trwania procesu.

Rola coacha ogranicza się wyłącznie do pracy w temacie i na materiale wprowadzonym $\mathrm{w}$ proces przez klienta. Tym samym coach pracujący za pomocą klasycznych metod coachingu, podejmuje aktywność wyłącznie w oparciu o treści wypowiadane bezpośrednio przez klienta. Taka postawa $\mathrm{w}$ procesie coachingowym nie pozwala utożsamić go z rolą przypisywaną trenerowi. Coach nie jest trenerem, a tłumaczenie anglojęzycznego terminu $\mathrm{w}$ ten sposób prowadzi do nieporozumień. Profesjonalny coach, o ile pracuje klasycznymi metodami coachingu, nie powinien wyrażać zgody na określanie siebie mianem trenera. Status trenera winien pozwolić sobie nadać tylko wtedy, gdy poza metodologiczną klasyką coachingu w zakres świadczonych usług pomocowych wprowadza także trenersko-szkoleniowe metody i narzędzia pracy

W świetle przyjętej przesłanki można zapytać: czym właściwie jest coaching? Odpowiedź na tak postawione pytanie okazuje się niejednoznaczna, gdyż formuły coachingu bywają antytetyczne. Warto jednak przywołać formułę coachingu zaproponowaną przez International Coach Federation — najstarszą, a zarazem największą, założoną przez Thomasa J. Leonarda

B. ZYCH: Coaching $w$ nurcie poznawczo-behawioralnym - podstawowe założenia $i$ modele pracy. W: Life Coaching. Relacje w równowadze. Red. K. RAmiRez-Cyzio. Warszawa 2010, s. 35.

${ }^{4}$ Klasyczna różnica pomiędzy metodyką coacha a metodyką trenera opiera się na tym, że o ile coach, niczym starożytny Sokrates, pozwala zobaczyć i wydobyć klientowi z siebie jego własne zasoby, a następnie skutecznie na nich pracować, o tyle trener w ymagając od osoby trenowanej lepszych wyników, niekoniecznie jest zainteresowany tym, skąd te zasoby pochodzą i jakim kosztem są generowane. Tym samym o ile dla trenera liczy się lepszy wynik osoby trenowanej (niekoniecznie jej zadowolenie), o tyle dla coacha ważniejsze jest to, by coachee pracując na swych zasobach odczuwał satysfakcję z osiąganych/realizowanych celów. Z opisu wynika również inna klasyczna różnica pomiędzy coachem a trenerem dotycząca budowania relacji z podopiecznym: o ile relacja coach — klient/coachee jest relacją równoległą/partnerską, o tyle relacja trener — osoba trenowana jest relacją nierównoległą; osobą rozkazująco-zarządzającą jest w tej relacji trener (osoba trenowana musi podporządkować się woli trenera). 
w 1995 roku, ogólnoświatową organizację coachingową, skupiającą środowisko profesjonalnych coachów. Zgodnie z postulatami wyróżnionej organizacji: coaching $\mathrm{w}$ wymiarze profesjonalnym definiuje się zwykle jako rozwijającą się $\mathrm{W}$ czasie, procesualną relację, która pomaga osiągnąc pożądane wyniki w życiu, w karierze, w firmach lub w organizacjach. Coaching według ICF to interaktywny proces umożliwiający klientom pogłębianie wiedzy o sobie, problemie lub temacie, z którym przychodzą na proces; to również postępowanie pozwalające na osiąganie lepszych wyników i poprawę jakości życia 5 .

${ }^{5}$ Zob. https://icf.org.pl Coaching oznaczać może także pomoc ludziom w dokonywaniu zmian $\mathrm{w}$ taki sposób, $\mathrm{w}$ jaki tego oczekują i pomoc $\mathrm{w}$ podążaniu w kierunku, w którym chcą podążać. Coaching jest procesem wzmacniania klienta w "samodzielnym dokonywaniu zamierzonej zmiany; w oparciu o własne wnioski i zasoby" (definicja: International Coaching Community) (iccpoland). Wreszcie coaching to również sprawne posługiwanie się trzema filarami budującymi dialog: ciszą, pytaniem i wyzwaniem, w celu udzielenia klientowi pomocy w realizowaniu konkretnego celu zawodowego. Zob. A. McLeod: Mistrz coachingu. Podręcznik dla menedżerów, HRowców i trenerów. Tłum. M. WitKowsKa. Gliwice 2008. Jenny Rogers, autorka jednego z najpopularniejszych podręczników coachingu, definiuje coaching w kategoriach współpracy z klientem, by ten, dzięki ukierunkowanemu, zindywidualizowanemu szkoleniu, znacząco i trwale usprawniał swoje działanie oraz doskonalił swoją efektywność $\mathrm{w}$ życiu osobistym i zawodowym. Jedynym celem coacha w procesie jest praca nad tym, aby klient rozwinął swój potencjał - tak, jak go sam zdefiniuje. Zob. J. Rogers: Coaching podstawy umiejętności. Tłum. K. Konarowska, D. PorażKa. Gdańsk 2010, s. 14. Coaching postrzegany bywa także w kategoriach bliskich terapii prowokatywnej Franka Farrelly'ego i ujmowany jest w formule: kontakt - humor prowokacja (odniesienie do terapii Farrelly'ego nie pozwala jednak na utożsamienie procesu coachingowego $\mathrm{z}$ terapią. Coaching wykorzystuje jedynie wybrane elementy postępowania znamiennego dla terapeutycznej formy pomocy). Proces coachingowy zainspirowany składnikami terapii Farrelly’ego opiera się na wartości życzliwości w sytuacji dobrych kontaktów międzyludzkich, humorze jako stanie rozbawienia oraz zachowaniachprowokatywnych, potwierdzających to, co klient lub podopieczny mówią o sobie (J. Hollander, J. WiJnberG: Coaching prowokatywny. Nowe podejście dla coachów, terapeutów, doradców. Tłum. M. SzczypińsKa. Wrocław 2008, s. 41). Rozważając zastosowanie terapeutycznych wątków w coachingu, warto przywołać także terapię nastawioną na osobę, która ewokuje w stronę humanistycznego podejścia C.R. Rogersa. Jednak ze względu na temat przewodni niniejszego artykułu, w tekście uwzględniam wyłącznie filozoficzne aspekty w coachingu, zaś szczegółową analizę psychologicznej koncepcji psychoterapeuty Rogersa i jej wpływ na coaching świadomie pomijam, odnosząc jednocześnie czytelników do innych moich artykułów $\mathrm{z}$ zakresu coachingu. 


\section{Filozoficzno-humanistyczne źródła coachingu}

Coaching, niezależnie od tego, jaką oficjalną definicję przyjmiemy, oznacza wyrażającą się w specyficznej formie rozmowy, spójną, gdyż stworzoną na coachingowej obecności, dialogiczną jedność z drugim człowiekiem. Warto w tym miejscu dodać, że coaching to także proces wypracowywania wspólnych emocji i wartości przez rozmówców oraz budowania partnerskiej więzi, oparty na specyficznej zależności zaufania. Podejściem tym coaching ujawnia swój głęboki, humanistyczny charakter.

Pytanie o człowieka i jego zasoby czy możliwości, a także biegłość w porozumiewaniu się - sygnowana wrażliwością coacha oraz wybitnym wyczuleniem na werbalne i pozawerbalne aspekty relacji: człowiek-człowiek które wykorzystuje praktyka coachingowa, jest zarazem istotą humanistyki i każdego pojedynczego procesu coachingowego. Skuteczna, pomocowa forma pracy z drugim człowiekiem, jeśli służyć ma udzieleniu mu wsparcia w samodzielnym dochodzeniu do celu, powinna opierać się na pewnym kapitale wiedzy coacha, niezależnie od tego, jakim typem coachingu zajmuje się on na co dzień'.

Praktykujący coach czerpie z rezerwuaru myśli intelektualnej, zwłaszcza filozofii i psychologii. Wspomniane dyscypliny, zwłaszcza filozofia, gwarantują coachingowi wsparcie w postaci trwałych fundamentów wiedzy o człowieku, jego otoczeniu, kondycji oraz miejscu w świecie. Jeśli więc chcemy spojrzeć na coaching jako zawód pomocowy lub formę świadczenia pomocy drugiemu człowiekowi, to wykazanie pewnych koincydencji między nim a filozofią jest potrzebne, a w pewnych sytuacjach wręcz konieczne.

U podstaw procesu coachingowego leży rudymentarne narzędzie filozofii. Narzędziem tym jest dialog. Trudno o oczekiwaną skuteczność pracy coacha i zadowolenie coachee bez niego. Niewiele osób zajmujących się coachingiem ma świadomość zależności między dialogiem w filozofii a praktyką coachingową. Dialogiczność coachingu zbliża tę formę pracy do dyskursu filozoficznego myślicieli europejskich epoki starożytnej, utożsamiających filozofię z praktyką życia i formą terapii. Przekonuje o tym popularna książka Czym jest filozofia starożytna Pierre'a Hadota, w której czytamy zdania wybrzmiewające niczym postulat pracy coacha. Hadot stwierdza między innymi: „dusza płodna może płodzić i owocować tylko w relacji

\footnotetext{
${ }^{6}$ Niezależnie od tego, czy współczesny coach pracuje w obszarach biznesu, rzeczywistości korporacyjnej/wielkich organizacji, rozwoju kariery, czy w sferze życia prywatnego swojego klienta, winien posiadać solidną wiedzę humanistyczną.
} 
z drugą duszą, w której dadzą się rozeznać konieczne przymioty; a relacja ta oprzeć się może tylko na żywym słowie, tylko na rozmowie"7.

Myślicielem, którego filozofia realizuje niniejsze żądanie, jest niewątpliwie starożytny Sokrates, o którym Søren Kierkegaard twierdził, że to człowiek jako taki, a nie - uczony rozważający abstrakcyjne pojęcia ${ }^{8}$. Bohater Platońskich Dialogów nie bez powodu przez współczesnych bywa określany mianem pierwszego coacha. Jego skoncentrowana na człowieku filozofia, odżegnując się od teoretycznych spekulacji, zapraszając człowieka do poznawania samego siebie, ergo: wzywając go do dokonania swoistej introspekcji własnego życia wewnętrznego, zyskuje wybitnie praktyczny, terapeutyczny i sprzyjający samopoznaniu charakter. W ten sposób spełnia istotne postulaty coachingu.

Warto dodać, że uzdrawiająco-terapeutyczne wątki pojawiają się w myśli starożytnej wyjątkowo często, dotykając problematyki życia pełnego i poczucia doskonałego szczęścia. W starożytności filozoficzna refleksja służy nade wszystko praktyce życia i etycznej zadumie nad ziszczeniem ideału Arystotelesowskiej eudajmonii w codzienności ${ }^{9}$. To właśnie filozofia hellenistyczna, niczym współczesny coaching, jest bliższa człowiekowi i ludzkim sprawom niż jakakolwiek wysublimowana forma wysoko unaukowionej, wyłącznie teoretycznej spekulacji filozoficznej jakże często uprawianej współcześnie w murach uniwersytetów. Dlatego prowadząc analizy ukazujące zależność między filozofią w jej praktycznym wymiarze a coachingiem, w miarę możliwości ograniczam spekulatywne wywody na rzecz pokazania filozofii jako sztuki życia i kojącej terapii o humanistycznej wrażliwości; dokonuję także próby zobrazowania filozofii jako swoistej „fortecy wolności, jaką człowiek może sobie stworzyć w swoim wnętrzu”10.

${ }^{7}$ P. Hadot: Czym jest filozofia starożytna? Tłum. P. Domański. Warszawa 2000, s. 86 .

${ }^{8}$ S. Kierkegand: Post-scriptum définitif et non scientifique. W: Idem: Oeuvres completes. Paryż 1977, s. 3.

${ }^{9}$ G. Reale: Historia filozofii starożytnej. T. 2. Platon i Arystoteles. Tłum. E.I. ZIELIŃSKI. Lublin 2001, s. 493-507.

${ }^{10}$ M. Montaigne: Próby. Tłum. T. Boy-Żeleński. Warszawa 1957, s. 1. 


\section{Filozofia wartości i filozofia dialogu jako formy humanistycznej terapii}

Stanowisko uznające filozofię za formę terapii w kontekście mówienia o filozofii w ogóle nie jest odkrywcze. Traktowanie jej jako dyscypliny, w której refleksja nad pathe, czyli emocjami i namiętnościami, życiem wewnętrznym oraz przywołaną wcześniej eudajmonią, oznaczającą wolne bądź autonomiczne spełnianie swojej istoty, a dalej, uznanie filozofii za dziedzinę duchowego dbania o siebie, duchowej troski o siebie, wolnego i aktywnego dążenia do pełni życia i szczęścia, jest czymś zupełnie naturalnym. Filozofia u swoich antycznych źródeł jawi się jako swoista techne życia; jako dziedzina troski o siebie; jako postać samoopieki lub swoistej pielęgnacji własnego człowieczeństwa w celu pozyskania niezależności (autarkia), wewnętrznej wolności (eleutheria) i panowania nad sobą $(\text { enkrateia })^{11}$. Również współcześnie filozofia może jawić się jako twórczy proces modelowania siebie bądź - jak wymownie, odwołując się do aspektów estetycznych, twierdzi francuski filozof Michel Foucault — tworzenia siebie jako czegoś pięknego ${ }^{12}$.

W estetyzującym ujęciu Foucaulta filozofia jest hermeneutyką subiektywności. Koncepcją współgrającą z wczesną myślą psychoanalityczną, której twórca, Sigmund Freud, pisze o stosowaniu podczas procesu ustalonych technik w celu dotarcia do tego, co przez człowieka-pacjenta prawdziwe i pożądane, a jednocześnie na pozór głęboko przez niego skrywane i niechętnie ujawniane. Żądanie ujawnienia skrywanego prowokuje nierzadko awersję Freudowskiego rekonwalescenta, to znaczy wzbudza jego opór. Zjawisko stawiania oporu, nie tylko na gruncie psychologicznej terapii, coachingu, ale także $\mathrm{w}$ filozofii (np. znany $\mathrm{z}$ historii filozofii opór współrozmówców Sokratesa), jest w pracy z drugim człowiekiem zjawiskiem niezwykle częstym.

W przypadku coachingu takie zahamowanie klienta podczas procesu przejawiać się może $\mathrm{w}$ próbach skracania procesu, zamknięciu się $\mathrm{w}$ sobie klienta, jego poczuciu rezygnacji, apatii, wybuchach arogancji, a nawet agresji ${ }^{13}$. Sytuacja zamknięcia się klienta lub podopiecznego na proces jest

${ }^{11}$ Zob. G. Reale: Historia filozofii starożytnej. T. 1. Od początków do Sokratesa. Tłum. E.I. ZIELIŃSKI. Lublin 2000, s. 335-340.

${ }^{12}$ K. Banicki: Filozofia jako terapia. Między Michela Foucaulta troska o siebie a autoterapia. W: Filozofia autorska: kolokwia filozoficzne II. Red. A. ZALEWSKI. Kraków 2011, s. $153-167$.

${ }_{13}$ Ibidem, s. 154. Zob. P. НАdot: Czym jest filozofia starożytna? Tłum. P. Domański. Warszawa 2000, s. $85-294$. 
skrajnie trudnym momentem $\mathrm{w}$ pracy coacha i wymaga przeprowadzenia podopiecznego przez zmianę.

Remedium na zaistniałą sytuację może być wówczas głęboka wiedza humanistyczna, zwłaszcza aksjologicznie zorientowana filozofia personalistyczna, skupiająca się na człowieku jako osobie. Reprezentantem tak ukierunkowanej myśli jest bez wątpienia Max Scheler. Jego gradacyjnie skonstruowany porządek aksjologiczny i towarzyszący mu antropologiczny system fenomenologii, w szczególności projekt materialnej etyki wartości, z powodzeniem może zostać uznany za podstawę wspomagania rozmaitych typów coachingu jako praktycznej formy pracy z drugim człowiekiem; podmiotem wchodzącym w oparty na wartościach dialog Ja-Ty.

To właśnie w Schelerowskim systemie filozofii węzłowe miejsce zajmuje otwarty na sferę wartości (aksjos), wartościujący ludzki podmiot, który mając świadomość zmiany — intencjonalnie odczuwa, emocjonalnie przeżywa, preferuje i poznaje ${ }^{14}$. Tak zdefiniowany podmiot, będący człowiekiem jako osobą, wchodzi w relację z drugim (także osobą) i w akcie akceptacji otwiera się, tworząc z nim potencjalną wspólnotę aksjologiczną, opartą na możliwości zauważania, rozpoznawania i realizacji określonych wartości. Ich uznanie niejednokrotnie uwarunkowane jest zmieniającą się sytuacją społeczno-kulturową ${ }^{15}$. Schelerowska filozofia podejmuje rozliczne kwestie z powodzeniem wykorzystywane obecnie w praktyce coachingowej.

W pracy coacha nieco inną filozoficzną inspirację stanowić może myśl Nicolaia Hartmanna - filozofa „ontycznej ważności powinności w sferze bytu realnego"16. W trakcie trwania coachingowego procesu etyka tego urodzonego w Rydze myśliciela stać się może podstawą głębokich ak-

${ }^{14}$ Zob. M. Scheler: Wolność, miłość, świętość. Tłum. G. SowinsKi. Kraków 2004, s. $9-36$.

${ }^{15} \mathrm{Z}$ zagadnieniem zmieniającej się sytuacji społeczno-kulturowej wiąże się Schelerowski system wartości uwzględniający: wartości hedonistyczne, związane z odczuwaniem przyjemności i doznawaniem zmysłowym (odczuwanie tego, co przyjemne-nieprzyjemne); wartości utylitarne (użyteczne-nieużyteczne); wartości witalne związane z ciałem i jego funkcjonowaniem: siłą witalną, siłą życiową (zdrowie-choroba); wartości duchowe: estetyczne (piękno-brzydota), poznawcze (prawda-fałsz), prawne; oraz wartości absolutne (religijne) odpowiadające za relację z tym, co nadmaterialne (świętość-nieświętość). Por. K. Wojtyla: Zagadnienie podmiotu moralności. Red. T. Styczeń, J.W. Galkowski, A. Rodziński, A. Szostek. Lublin 2001. Zob. K. WojtyŁa: Osoba i czyn oraz inne studia antropologiczne. Lublin 2000. Zob. S. KowalcZYK: Człowiek w poszukiwaniu wartości. Elementy aksjologii personalistycznej. Lublin 2006. Zob. M. SCHELER: Człowiek i historia. Tłum. A. Węgrzecki. W: M. Scheler: Pisma z antropologii filozoficznej i teorii wiedzy. Tłum. S. Czerniak, A. WęGrzecki. Warszawa 1987, s. 150-190. Zob. M. Scheler: Der Formalismus in der Ethik und die materiale Wertethik. Freiburg i. B. - Halle a. d. Saale 1916.

16 A.J. Noras: Nicolaia Hartmanna koncepcja wolności woli. Katowice 1998, s. 14. 
sjologicznych - uwzględniających zmianę - poszukiwań. U podstaw Hartmannowskiej myśli leży bowiem pytanie: co (powinienem) czynić? Co (powinniśmy) czynić? Ta Kantowska indagacja, której źródłem jest — jak twierdzi Hartmann - zmieniający się horyzont aksjologiczny, nie zakłada gotowej odpowiedzi, lecz zaprasza do niezależnych poszukiwań i samodzielnego wyznaczania sobie działań oraz odkrywczego odpowiadania na nurtujące jednostkę pytania (na przykład pytania o kształt życia lub jego jakość).

Etyka filozoficzna Hartmanna pozwala rozwijać ludzką wrażliwość, pozwala uchwytywać valor oraz kształtować swój własny aksjologiczny organ, by za jego pośrednictwem urabiać własną dojrzałość i godność osobową. $\mathrm{W}$ takim systemie etyki, podobnie jak w myśli Schelera, człowiek prezentuje się jako nosiciel nadmaterialnej zasady — pierwiastka osobowego, za sprawą którego staje się podmiotem zdolnym do realizacji wartości moralnych ${ }^{17}$. Człowiek jako moralny podmiot, którym jest aprioryczne Ja - idea osoby przeciwstawiona osobie empirycznej, jest jednością, dlatego również wtedy, gdy człowiekowi jako takiemu nadamy Pascalowski status istoty nędznej, znikomej, słabej i efemerycznej, to - poprzez zwrot ku sferze aksjos jako sferze tego, co obiektywne, godne i cenne - będzie jawił się on także jako wolny i wartościujący otaczającą rzeczywistość architekt wszelkiej sensowności oraz myślący i czujący kreator sensu oraz celu ${ }^{18}$.

W takim ujęciu człowiek będąc podmiotem wartości i stanowiąc unikatową jedność, jest wyjątkową istotą zdolną nadawać światu sens, ponieważ dysponuje metafizycznym połączeniem ze światem wartości; dysponuje też spontaniczną, własną dynamiką jako zdolnością do skłaniania się ${ }^{19}$. Nadając światu sens, człowiek jako osoba urzeczywistnia moralne wartości wyższe $^{20}$. Według założeń Hartmannowskiej etyki taki człowiek jako „,podmiot moralny jest istotą patrzącą w przyszłość, troszczącą się, ustanawiającą cele, działającą i w działaniu swobodnie rozstrzygającą; [jest osobą A.M.], która ma zmysł wartości [...], posiada wiedzę o dobru oraz złu i sama potrafi być dobrą lub złą" ${ }^{21}$. Wyróżnione systematy etyczne Schelera i Hartmanna odgrywają istotną rolę w kształtowaniu człowieka jako istoty wolnej, dialogicznej, wartościującej, wrażliwej, myślącej, czującej i zdolnej do podjęcia — jakże bliskiego coachingowi - wysiłku samorozwoju.

17 J. FILEK: Filozofia jako etyka: eseje filozoficzno-etyczne. Kraków 2001.

18 B. Pascal: Myśli. Tłum. T. ŻeleńsKi-Boy. Warszawa 1989, s. 65-88.

19 Zob. I. Kant: Krytyka władzy sądzenia. Tłum. J. GaŁeCKI. Warszawa 1986, s. 417. Por. A.J. NoRAs: Nicolaia Hartmanna koncepcja wolności woli..., s. 48.

${ }^{20}$ Ibidem, s. 50.

${ }^{21}$ Ibidem, s. 51. 
Interaktywność człowieka zachęca także do podjęcia rozważań nad znaczeniem filozofii dialogu w coachingu. Chociaż ślady tego dwudziestowiecznego nurtu filozofii pojawiają się już w aksjologicznym projekcie wspomnianego wcześniej Maxa Schelera oraz w personalizmie Ferdinanda Ebnera, to jednak dopiero systemy Martina Bubera, Emmanuela Lévinasa i Józefa Tischnera potęgują intelektualno-humanistyczne znaczenie tego coachingu. Filozofia dialogu, nazywana zamiennie filozofią spotkania, koncentruje się zarówno na problemie człowieka, etyce wartości, jak i atrybucie interakcji, dlatego wręcz pożądana jest próba przeanalizowania myśli przywołanych właśnie filozofów w kontekście coachingu.

Filozofia austriackiego myśliciela i religioznawcy Martina Bubera pozwala zobaczyć w człowieku byt relacyjny, dialogiczny, którego życie ukonkretnia się w formie spotkania. Według autora Dialogisches Leben - gesammelte philosophische und pädagogische Schriften, człowiek to stworzenie zawsze zwrócone ku czemuś i kierujące się wartościami prostoty, pokory, radości i szczęścia. To Buberowskie dictum nakłania do zobaczenia w drugim człowieku istoty, która wchodząc w stosunek Ja-Ty, rozpoznaje „Ty” jako świadomą osobę, partnera dyskusji erygującego ziszczenie się dobra. Coaching także ma na celu swoiste wskrzeszenie w kliencie poczucia radości, szczęścia w drodze zmierzania do celu jako cennego dla klienta dobra.

Pewną bliską coachingowi subtelność wyraża również filozofia Emmanuela Lévinasa. Człowiek w systemie Lévinasa prezentuje się jako integralna całość i poznająca podmiotowość jednostkowego, a zarazem konkretnego bytu, który zderza się z codziennością, bywa w różnych sytuacjach, podejmuje autonomiczne decyzje, zajmuje określone stanowiska wobec wielości zdarzeń oraz świadomie i odpowiedzialnie wdraża w życie wybrane przez siebie wartości. Podejmując wysiłek realizacji określonych wartości, podlega ocenie moralnej, wchodzi w sytuacje bycia-dla-drugiego, pozostaje w procesie „dojrzewania do podjęcia odpowiedzialności”22 i ustanowienia relacji etycznej. Tu także coach dostrzeże elementy, nierzadko ujawniające się podczas coachingowego procesu, czyli partycypację w samodzielnie podejmowanych przez klienta decyzjach, rejestrowanie dokonywanych przez klienta podczas procesu wyborów aksjologicznych.

Podjęty przez francuskiego filozofa wysiłek skupienia uwagi na dobru drugiego ma na celu uwrażliwić człowieka na elementarne wartości, decydujące o sensie i jakości ludzkiego życia, oraz poczuciu szczęścia. W każdym doświadczeniu spotkania Lévinas zawiera wymóg etyczny. Spotkanie z drugim w relacji etycznej, budowanej na fundamentach wartości odpowiedzialności, żydowsko-litewski filozof określa mianem epifanii twarzy. Spotkanie

${ }^{22}$ K. WieczoreK: Lévinas a problem metafizyki. Katowice 1992, s. 96-97. 
z twarzą innego/drugiego nakłada zobowiązania właściwego odczytania przekazywanej (przez drugiego) treści, a ponieważ twarz innego objawia się w mowie, owa treść jest właśnie przekazywana poprzez mowę. W ten sposób mowa staje się nośnikiem treści. Jako nośnik treści znaczeniowej jest cechą swoiście ludzką i stanowi clou wypowiedzi. Natomiast wypowiedź zawsze ma charakter warstwowy: o ile jej pierwsza warstwa (dire) przenika do świadomości odbiorcy, o tyle druga warstwa (dit), jako nieprzenikliwa i niewspółmierna, jest wyrazem transcendencji innego ${ }^{23}$. Podobna warstwowość wypowiedzi ujawnia się w coachingowym dialogu, za pośrednictwem którego coachee ujawnia treści wspomagające zarówno tok coachingowego procesu, jak również treści sprzyjające procesowi samopoznania coachee: $\mathrm{w}$ procesie coachingowym, coachee poprzez autorefleksję wychodzi poza dotychczasową wiedzę o sobie i problemie, który przywiódł go do coacha.

Wizję człowieka dialogicznego kreśli również fenomenolog i katolicki prezbiter Józef Tischner. Tischnerowski człowiek umieszczony w horyzoncie dobra i wartości wypełnia się w dialogicznej relacji pytającego i zapytanego. Pytający i zapytany tworzą, podobnie jak dzieje się to w coachingowym procesie, wspólną przestrzeń: scenę relacji rozgrywającego się dramatu. Oboje stają w konkretnej dramatycznej sytuacji zderzenia wartości. Sytuacja ta jest szansą na otwarcie się i wspólne poszukiwanie. Fakt ten pozwala nazwać system Tischnera szczególną przestrzenią poszukiwań antropologicznej wiedzy na temat człowieka, mającą na celu możliwie najlepsze i najpełniejsze jego zrozumienie w wymiarze aksjologicznym i agatologicznym. W Tischnerowskim programie filozofii człowiek jest uczestnikiem dialogu, a jednocześnie istotą wolną, tęskniącą za tym, co dobre, w pełni odpowiedzialną za swoje czyny i uprawnioną do aksjologicznego, wartościującego samokształtowania. Wreszcie człowiek to także istota wrzucona w świat, w nieprzewidywalne wydarzenia i sytuacje, pod wpływem których uznaje różne, nie zawsze pozytywne, wartości.

Jak pisze Tischner, nierzadko zrozpaczony człowiek pozwala sponiewierać się wartościom negatywnym. Wówczas zabija on siebie w sobie, popada w aksjologiczne szaleństwo, traci siebie przez siebie - aksjologicznie umiera. Jednak ,,...] nawet jeśli ten »aksjologiczny człowiek umark« [...] to znaczy, że istniał, a jeżeli istniał, to znaczy, że może się ponownie narodzić. Wciąż bowiem obracamy się w polu ogromnych możliwości. To dużo, zwłaszcza gdy uwzględni się poglądy tych, którzy sądzą, że nie ma już żadnych możliwości" 24 . Rzecz w tym, by uwierzyć i wykorzystać nową szansę bądź możliwość; by pochylić się nad zrozpaczonym człowiekiem z dewizą bycia,

${ }^{23}$ E. LÉvinas: Całość i nieskończoność. Esej o zewnętrzności. Tłum. M. Kowalska. Warszawa 2002, s. 227-344.

24 J. Tischner: Spór o istnienie człowieka. Kraków 1998, s. 43. 
wyrażoną hasłem: „no, bądź”25. Proces coachingowy także zakłada taki, właściwy systemowi Tischnera, postulat możliwości bycia jako ponownego odkrycia siebie: poznania siebie w wymiarze aksjologicznym. Każdy proces coachingowy jest również zderzeniem systemów wartości coacha i coachee. Coach, pozwalając coachee być, zawiesza w czasie procesu osobiste sposoby wartościowania i skupia uwagę na swoim rozmówcy, wydarzeniach oraz sytuacjach, z którymi ten mierzy się $\mathrm{w}$ rutynie codzienności.

\section{Zakończenie}

Podjęta próba ukazania wybranych związków filozofii i coachingu pozwala potwierdzić tezę, w myśl której przestrzeń pracy coacha w znacznej mierze jest przestrzenią humanizmu subtelnie znaczoną filozofią; jest wiedzą humanistyczną, która jawi się jako swoista podstawa dialogicznej relacji, w tym korelacji coachingowej. Humanizm definiuję tu jako obszar troski o potrzeby, cele, godność, autonomię i samorozwój człowieka będącego transcendującą jednostką, która stanowi centrum procesu coachingowego. Przyjmuję także, iż obszar pracy coachingowej stanowi dziś swoisty amalgamat nurtów filozoficznych i skoncentrowanych na człowieku światopoglądów, które praktycy coachingu, podobnie jak przedstawiciele innych zawodów pomocowych ${ }^{26}$, wykorzystują na co dzień w swojej pracy.

Zdając sobie sprawę z ograniczeń niniejszego artykułu; faktu, że powzięty temat można byłoby rozważyć znacznie głębiej i szerzej, pragnę potwierdzić tezę o aktualności wyróżnionych w tekście koncepcji filozoficznych, których humanistyczne elementy raz po raz ujawniają się w praktyce coachingowej. Współczesne formy pracy $\mathrm{z}$ drugim człowiekiem, zwłaszcza coaching, dowodzą aktualności wielu filozoficznych programów, stanowiąc niejako dowód możliwości wykorzystania szeroko pojętej wiedzy humanistycznej w praktyce zawodowej coachingu.

25 J. TisChner: Świat ludzkiej nadziei. Kraków 2000, s. 183.

${ }^{26}$ Wśród zawodów pomocowych (helping professions), określanych często mianem zawodów pożytku społecznego, wymienia się głównie: pracownika socjalnego, psychologa, psychoterapeutę, psychoanalityka, asystenta osoby niepełnosprawnej, opiekuna środowiskowego. Do wyróżnionej grupy od niedawna należy także coach, który - wykorzystując profesjonalne, coachingowe metody i narzędzia pracy służy pomocą zarówno w kwestiach zawodowych, jak i prywatnych/osobistych. 


\section{Blibliografia}

BANICKI K.: Filozofia jako terapia. Między Michela Foucaulta troska o siebie a autoterapia. W: Filozofia autorska: kolokwia filozoficzne II. Red. A. ZALEWSKI. Kraków 2011, s. 153-167.

Buber M.: Ja i Ty. Wybór pism filozoficznych. Tłum. J. DoKtór. Warszawa 1992. (2015), URL = http://www.icf.org.pl/p179coaching.html [dostęp 24.07.2015].

(2015), URL = http://www.iccpoland.pl/pl/strefa_wiedzy/czym_jest_coaching [dostęp: 24.07.2015]

(2017), www.swiatcoachingu.pl/2011-09-27-04-13-15/definicja/440-zawod-coach-wklasyfikacji-zawodow-i-specjalnosci [dostęp: 02.01.2018]

Coaching jako konstruktywny dialog. Red. L.D. CzArkowska.Warszawa 2016.

Coaching transformacyjny jako droga ku synergii. Red. L.D. CzARKowskA. Warszawa 2014.

Czakon T.: Wolność i dobro. Problem wolności w katolickiej filozofii społecznej w Polsce po 1989 roku. Katowice 2005.

FILEK J.: Filozofia jako etyka: eseje filozoficzno-etyczne. Kraków 2001.

Filozofia jako sztuka życia. Teorie, modele $i$ wzorce dla doradztwa filozoficznego. Red. A. WoszczYK, D. OLEsińsKI. Katowice 2013.

Gallway W.T.: Wewnętrzna gra: tenis. Trening mentalny w sporcie $i$ w życiu. Tłum. R. MADEJCZYK. Warszawa 2015.

Hadot P.: Czym jest filozofia starożytna? Tłum. P. Domański. Warszawa 2000.

Hartmann N.: Ethik. Berlin 1926.

Hollander J.: Wijnberg, J.: Coaching prowokatywny. Nowe podejście dla coachów, terapeutów, doradców. Tłum. M. SzczypińsKA. Wrocław 2008.

Kant I.: Krytyka władzy sądzenia. Tłum. J. GAŁECKI. Warszawa 1986.

KierkegaARD S.: Post-scriptum définitif et non scientifique. W: IDEM: Oeuvres completes. Paryż 1977.

Kowalczyk S.: Człowiek w poszukiwaniu wartości, Elementy aksjologii personalistycznej. Lublin 2006.

LÉvinas E.: Całość i nieskończoność. Esej o zewnętrzności. Tłum. M. Kowalska. Warszawa 2002.

McLeod A.: Mistrz coachingu. Podręcznik dla menedżerów, HR-owców i trenerów. Tłum. M. Witkowska. Gliwice 2008.

Montaigne M.: Próby. Tłum. T. Boy-Żeleński. Warszawa 1957.

Noras A.J.: Nicolaia Hartmanna koncepcja wolności woli. Katowice 1998.

PAscal B.: Myśli. Tłum. T. ŻELEŃski-Boy. Warszawa 1989.

ReAle G. Historia filozofii starożytnej. T. 1-2. Tłum. E.I. ZIELIŃSKI. Lublin 2001. Rogers J.: Coaching podstawy umiejętności. Tłum. K. Konarowska, D. PorażKa. Gdańsk 2010.

Rosinski P.: Globalny coaching: podejście zintegrowane. Tłum. A. NiEDzIESKA, P. NiEDZIESKI. Warszawa 2011. 
Scheler M.: Człowiek $i$ historia. Tłum. A. Węgrzecki. W: Idem: Pisma z antropologii filozoficznej $i$ teorii wiedzy. Tłum. S. Czerniak, A. WęGrzecki. Warszawa 1987.

Scheler M.: Der Formalismus in der Ethik und die materiale Wertethik. Freiburg i.B. - Halle a. d. Saale 1916.

Scheler M.: Wolność, miłość, świętość. Tłum. G. SowinsKi. Kraków 2004.

Tischner J.: Spór o istnienie człowieka. Kraków 1988.

Tischner J.: Świat ludzkiej nadziei. Kraków 2000.

WieczoreK K.: Lévinas a problem metafizyki. Katowice 1992.

WojtyŁa K.: Osoba i czyn oraz inne studia antropologiczne. Lublin 2000.

WojtyŁa K.: Zagadnienie podmiotu moralności. Red. T. Styczeń, J.W. GaŁkowski, A. Rodziński, A. Szostek. Lublin 2001.

ZYCH B.: Coaching $w$ nurcie poznawczo-behawioralnym - podstawowe założenia $i$ modele pracy. W: Life Coaching. Relacje w równowadze. Red. K. RAmIREz-Cyzio. Warszawa 2010, s. 35-47. 